\section{OPEN ACCESS}

Edited by:

Johann G. Zaller,

University of Natural Resources and

Life Sciences Vienna, Austria

Reviewed by:

Vera Lucia Imperatriz-Fonseca,

University of São Paulo, Brazil

Bindu Sadanandan,

Ramaiah Institute of Technology, India

${ }^{*}$ Correspondence:

Mauricio González-Chang mauricio.gonzalez@uaysen.cl

Specialty section:

This article was submitted to Agroecology and Ecosystem Services,

a section of the journal

Frontiers in Sustainable Food Systems

Received: 01 April 2020

Accepted: 04 August 2020 Published: 11 September 2020

Citation:

Wyckhuys KAG, González-Chang M, Adriani E, Albaytar AB, Albertini A, Avila G, Beltran MJB, Boreros $A D$,

Fanani MZ, Nguyen DT, Nguyen G,

Nurkomar I and Tiwari S (2020)

Delivering on the Promise of Biological

Control in Asia's Food Systems: A Humboldtian Perspective.

Front. Sustain. Food Syst. 4:140. doi: 10.3389/fsufs.2020.00140

\title{
Delivering on the Promise of Biological Control in Asia's Food Systems: A Humboldtian Perspective
}

\author{
Kris A. G. Wyckhuys ${ }^{1,2,3,4}$, Mauricio González-Chang ${ }^{5 *}$, Evie Adriani ${ }^{6}$, \\ Annabelle B. Albaytar ${ }^{7}$, Alice Albertini ${ }^{8}$, Gonzalo Avila ${ }^{9}$, Marie Joy B. Beltran ${ }^{10}$, \\ Ariel D. Boreros ${ }^{11}$, Muhammad Z. Fanani ${ }^{12}$, Duc T. Nguyen ${ }^{13}$, Giang Nguyen ${ }^{14}$, \\ Ihsan Nurkomar ${ }^{15}$ and Sundar Tiwari ${ }^{16}$
}

${ }^{1}$ Institute for Plant Protection, China Academy of Agricultural Sciences, Beijing, China, ${ }^{2}$ Fujian Agriculture and Forestry University, Fuzhou, China, ${ }^{3}$ University of Queensland, Brisbane, QLD, Australia, ${ }^{4}$ Chrysalis Consulting, Hanoi, Vietnam, ${ }^{5}$ Department of Sustainable Biosphere, Universidad de Aysén, Coyhaique, Chile, ${ }^{6}$ Ichsan University, Gorontalo, Indonesia, ${ }^{7}$ Institute of Weed Science, Entomology and Plant Pathology, University of the Philippines Los Baños, Los Baños, Philippines, ${ }^{8}$ Institute of Life Sciences, Scuola Superiore Sant'Anna, Pisa, Italy, ${ }^{9}$ The New Zealand Institute for Plant and Food Research Limited, Auckland, New Zealand, ${ }^{10}$ National Crop Protection Center, University of the Philippines Los Baños, Los Baños, Philippines, ${ }^{11}$ Regional Crop Protection Center XII, Tacurong City, Philippines, ${ }^{12}$ Bogor Agricultural University, Bogor, Indonesia, ${ }^{13}$ Vietnam National University of Agriculture, Hanoi, Vietnam, ${ }^{14}$ University of Agriculture and Forestry, Hue University, Hue, Vietnam, ${ }^{15}$ Universitas Muhammadiyah Yogyakarta, Yogyakarta, Indonesia, ${ }^{16}$ Agriculture and Forestry University, Bharatpur, Nepal

During the late twentieth century, the "Green Revolution" attained wide-ranging poverty alleviation, food security and improved nutrition across rural Asia. As these achievements were often reached at large environmental costs, "greener" trajectories urgently need to be traced for Asia's agri-food systems. In this sense, agro-ecological and biodiversity-based (ABB) farming systems can provide sufficient food, lift resource-use efficiencies and lower fossil-fuel dependencies while safeguarding the environment. Here, we systematically assess past progress and prospects for biodiversity-based pest management -or biological control (BC)- in five Asian countries. We characterize the extent to which $\mathrm{BC}$ science has matured, translated into practice and attained "real-world" outcomes within the prevailing farming systems of each country. To achieve this, we revert to the world-view of the eighteenth century naturalist Alexander von Humboldt. Doing so, we represent the extent to which BC science has progressed along a six-step "impact pathway" -from a description of on-farm biodiversity, over ecosystem service delivery to verifiable socio-economic outcomes. Our work pinpoints ways to strategize ABB science for an accelerated, evidence-based uptake by end-users within local agri-food systems. By entwining our Humboldtian "nature-culture" perspective with farmer-scientist co-innovation, bolstered awareness-raising and supportive policies, ABB farming transitions could be initiated that are prone to deliver concrete, desirable agro-ecological outcomes at local and regional scales.

Keywords: agroecology, biodiversity, biological control, paradigm shift, holistic perspective 


\section{INTRODUCTION}

In the early 1800's, the German naturalist, explorer and avid field scientist Alexander von Humboldt laid out his vision of nature as "a living whole" (Jackson, 2009; Wulf, 2015). Driven by a sense of wonder and devotedly measuring and tabulating innumerable phenomena, von Humboldt saw nature as a web of life in which fauna and flora, the elements, climatic processes, and human beings were all closely interconnected. Adopting a holistic, fused "nature-culture" perspective, von Humboldt tirelessly pursued a conceptual unification of Earth system sciences, planted the seed for agricultural sustainability or conservation ecology disciplines, inspired environmentalism and foresaw human-induced global change (Zimmerer, 2006; Jackson, 2009). This interdisciplinary "Humboldtian perspective," which speaks directly to pressing human concerns, is valued to mitigate today's global environmental crisis and to help redesign the world's agrifood systems (DeFries and Nagendra, 2017; Acevedo et al., 2018; Vandermeer et al., 2018; Yletyinen et al., 2019).

Conventional agriculture -as a dynamic, inter-connected socio-ecological system- entails land clearance, ecosystem mismanagement and chemical pollution, and is thus a major contributor to environmental change (Dirzo et al., 2014; Maxwell et al., 2016; Isbell et al., 2017). By depleting limited resources, adding to biodiversity loss and degrading ecosystem services over often extended spatial and temporal scales, many of today's agrifood production systems exert a pervasive influence on the "safe operating space" for global socio-economic development (Steffen et al., 2015; Springmann et al., 2018). The above phenomena are believed to be especially exacerbated in eastern Asia, a region that houses $\sim 50 \%$ of the world's agri-food production and which has experienced a steady $3.8 \%$ annual growth in agricultural output since the 1960's (Alston and Pardey, 2014).

Over the past 50 years, the "Green Revolution" (GR) has filled Asia's rice bowls, permitted a "quantum leap" in food production and defined much of the region's (agricultural) growth trajectories (Pingali, 2012). "Packaged" GR seed $\times$ chemical technologies and intensified farming schemes did secure a steady supply of nutrient-rich foods, but also degraded the resource base of local agriculture, imperiled farmers' health and imposed serious environmental costs across agro-landscapes (Tilman, 1998; Brainerd and Menon, 2014; Kleijn et al., 2019). As a GR hallmark, farmers' dependency upon synthetic pesticides didn't remain confined to rice settings but infiltrated other cropping systems, e.g., with present-day vegetable growers in Vietnam overspending as much as US $\$ 329 / \mathrm{ha} /$ cycle on pesticides (Schreinemachers et al., 2020) or Bangladeshi eggplant producers applying 150-200 chemical sprays per year (Pretty and Bharucha, 2015). As such, pesticide application regimes involve vast externalities for human and environmental health, estimated at up to $\$ 106 /$ ha for Thailand's horticulture operations (Praneetvatakul et al., 2013; Jepson et al., 2020). These costs are likely to rise with the steady resistance development of prominent pests to "new generation" insecticides (Gorman et al., 2008; Jørgensen et al., 2018). Yet, experiences with "farmer first" training approaches in various Asian countries provide compelling evidence of how agro-chemical use in rice systems can be curbed while sustaining or even increasing yield, food output or farm revenue (Matteson, 2000; Pretty and Bharucha, 2015; Gurr et al., 2016). A tactical combination of agro-ecology science, targeted policies and carefully orchestrated extension campaigns achieved a full $70-75 \%$ reduction in pesticide use in Indonesia, Philippines or Vietnam's Mekong Delta during the 1990 's, though these achievements have been largely undone in recent decades (Bottrell and Schoenly, 2012; Thorburn, 2015).

Concurrent with the rise of GR technologies, Humboldtian "systems approaches" have been increasingly advocated as a guiding premise for sustainable, ecologically-centered pest management (Ruesink, 1976; Altieri, 1984; Teng and Savary, 1992; Lewis et al., 1997; Coll and Wajnberg, 2017). In Asian rice systems, an integrative assessment of the full ensemble of drivers and determinants of pesticide use permitted an effective promotion of sustainable agriculture (Pretty et al., 2018). This involved a comprehensive appraisal of the resident biodiversity in rice ecosystems (Schoenly et al., 1998), quantification of associated ecosystem processes (Settle et al., 1996) and due attention to farmers as decision-makers and agents of change (Röling and Van De Fliert, 1994; van de Fliert et al., 2007). A central tenet of this "systems approach" was invertebrate biological control; an ecosystem service that is valued at \$4.5-13.6 billion annually for US agriculture alone (Pimentel et al., 1997; Losey and Vaughan, 2006) and which can be bolstered through the in-field enhancement of beneficial, pestkilling organisms (Bale et al., 2008; Naranjo et al., 2015). As such, ecosystem services were effectively translated into farmer decision-making (Daily et al., 2009) and replaced chemically intensive GR technologies across Asian rice agro-landscapes.

However, as evident in historical pesticide use patterns (Pretty and Bharucha, 2015), the effective harnessing of biodiversity for (endemic) pest control was largely restricted to Asia's rice systems and its adoption proved transient in nature. In other systems, science on biodiversity and ecosystem functioning is regularly lagging, remains stuck in disciplinary "silos" and fails to deliver concrete outcomes (Daily et al., 2009; ChaplinKramer et al., 2019; Hines et al., 2019; Kleijn et al., 2019; González-Chang et al., 2020). A recently developed web-based tool (www.biodiversityfunction.com) outlines a "spiral approach" that provides an explicit pathway from the concept of biodiversity to produce agro-ecological outcomes at farm level (GonzálezChang et al., 2020). Thus, the spiral approach can help to identify the knowledge gaps that need to be filled for creating serviceproviding protocols (SPP; sensu Gurr et al., 2017; GonzálezChang et al., 2020) and to better understand the interactions and connectedness between the steps arising from the biodiversity concept. This approach provides the basic steps needed to devise agro-ecological and biodiversity-based (ABB) agri-food systems.

In this study, we provide a retrospective assessment of the extent to which biological control science has facilitated the necessary knowledge and tools to deliver such concrete, measurable agro-ecological outcomes in Asian farming systems. First, we conducted a systematic literature review of (published) biological control research in five Asian countries over the past 50 years. Next, we assigned each individual publication to one or more categories (and related sub-themes) within the spiral 
approach (González-Chang et al., 2020). Lastly, we visualized temporal dynamics in biological control science and plotted progress per geography and commodity. Our "Humboldtian" perspective permits identifying shortcomings in the integrative social-ecological research that revolves around $\mathrm{ABB}$ farming systems, and helps draw trajectories to foment transformational change in local agri-food systems.

\section{MATERIALS AND METHODS}

Our assessment of historic biological control research progress was conducted in a step-wise manner. First, literature searches were run on different search engines to get a full set of scientific publications from different sources. An initial search was run on the Web of Science (WoS) Core collection database (1900-2020), thus covering over 21,100 peer-reviewed journals, conference proceedings and book data published globally. Studies that covered integrated pest management (IPM) without explicitly mentioning biological control in all fields were not taken into consideration. A core set of papers on insect biological control was consolidated by using the Boolean search string "ALL = country AND (field OR crop) AND ("biological control” OR biocontrol OR "natural enem*" OR predat* OR parasit*) AND (pest*)," as defined by the authors. Search strings were adapted to obtain results for each of five different Asian countries, i.e., Indonesia, Nepal, Philippines, Thailand, and Vietnam. For the latter country, separate searches were performed using the spaced and unspaced name, i.e., "Vietnam" and "Viet Nam." Queries were run using a University of Queensland staff subscription between February 15 and March 10, 2020, accessed through a regular internet connection from Hanoi, Vietnam. The above Web of Science search results were complemented with records obtained with the new scholarly database Dimensions (Thelwall, 2018) and with non-exhaustive queries of national journals, regularly featuring work in languages different from English. The latter searches yielded a fair number of scientific publications for the Philippines, Indonesia and Vietnam, but likely proved incomplete in Thailand and Nepal.

Next, abstracts of the resulting papers were screened and less pertinent studies were omitted from the analysis. This yielded a total of 430 publications covering different facets of biological control, across all five Asian countries. Publications solely comprised biological control interactions between invertebrate resource items (i.e., herbivorous prey, crop pests) and either invertebrate or vertebrate consumers (i.e., natural enemies such as carnivorous predators or endo-parasitoids). Publications that addressed biological control with micro-organisms (i.e., entomopathogenic fungi, bacteria, viruses, microsporidia) were not taken into consideration. Also, publications that solely described on-farm invertebrate biodiversity without explicitly listing either presence, abundance, or diversity of insect natural enemies (i.e., predators, parasitoids) were not taken into consideration. As such, literature records covered a range of research activities under the three subdisciplines of classical (or importation), augmentation and conservation biological control (Bale et al., 2008; Heimpel and Mills, 2017).
Within this extensive literature base, each individual publication was screened to determine the exact research focus. Published research was thus assigned to one or more themes within a six-step sequential "impact pathway" as adapted from concepts presented in González-Chang et al. (2020). More specifically, we considered the following six core thematic areas or categories: (1) biodiversity, (2) core attributes of the ecosystem service provider (ESP), (3) ESP population ecology, (4) service providing protocols (SPP), (5) delivery systems and implementation pathways, and (6) socio-ecological outcomes. The latter theme accounts for agro-ecological practices (e.g., flower strips, intercrops) that have a clear impact in the socioeconomic domain, i.e., farmer income and farm-level revenue while including crop yield as an imperfect proxy of those measures. Although the concept of agro-ecological outcomes encompasses social, economic and ecological dimensions (González-Chang et al., 2020), here we have explicitly included economic aspects in the socio-ecological-outcomes step, as poverty in Asia has been recently associated with environmental degradation and pollution (Khan, 2019). The first theme refers to the discovery and description of the diversity of insect natural enemies that occur within farm settings. For the second theme, to assess the available knowledge on ESP core attributes, we considered different sub-themes that help anticipate the effectiveness of a natural enemy in population regulation, i.e., prey specificity, reproductive capacity, and environmental adaptability (DeBach and Rosen, 1991). As such, elements of the biology, life history, mass-rearing potential, or host acceptance behavior of a consumer item were covered (Table 1). Similarly, for the third theme on ESP population ecology, we logged studies that entailed either laboratory or in-field evaluations of biological control agents e.g., by using life table and mortality analyses, exclusion assays or dietary assessments (Fisher et al., 1999). Under theme four, we logged all published research that assessed how farmers can put functional biodiversity into practice (Gurr et al., 2017; González-Chang et al., 2020), e.g., by refraining from pesticide use, diversifying crop or farm settings, establishing flower strips (Barbosa, 1998; Landis et al., 2000; Gurr et al., 2016). Lastly, for theme five, we recorded the number of publications that involved end-user perspectives, e.g., farmer knowledge and decision-making, socio-political dimensions or agricultural extension strategies. By thus assigning published work to each these specific categories, it was possible to quantify the extent to which each research endeavor contributed to achieving concrete, verifiable agro-ecological outcomes.

For each literature record, we also logged the year of publication, focal commodity, target resource item (e.g., herbivorous prey, crop pest), consumer item (i.e., natural enemy) and noted whether the work involved field research, laboratory assays, mathematical modeling, farmer surveys or reviews. For resource and consumer items, the exact taxonomic classification was noted. Individual commodities were assigned to different crop categories as defined by the United Nations Food and Agriculture Organization (UN-FAO). Once pertinent literature records were classified within these six categories, a strategy is suggested to enhance $\mathrm{ABB}$ systems for each respective Asian country. Yet, in order to avoid a reductionist, pest-centric 
TABLE 1 | Comparative extent of scientific attention to different themes along a six-step, outcome-oriented impact pathway.

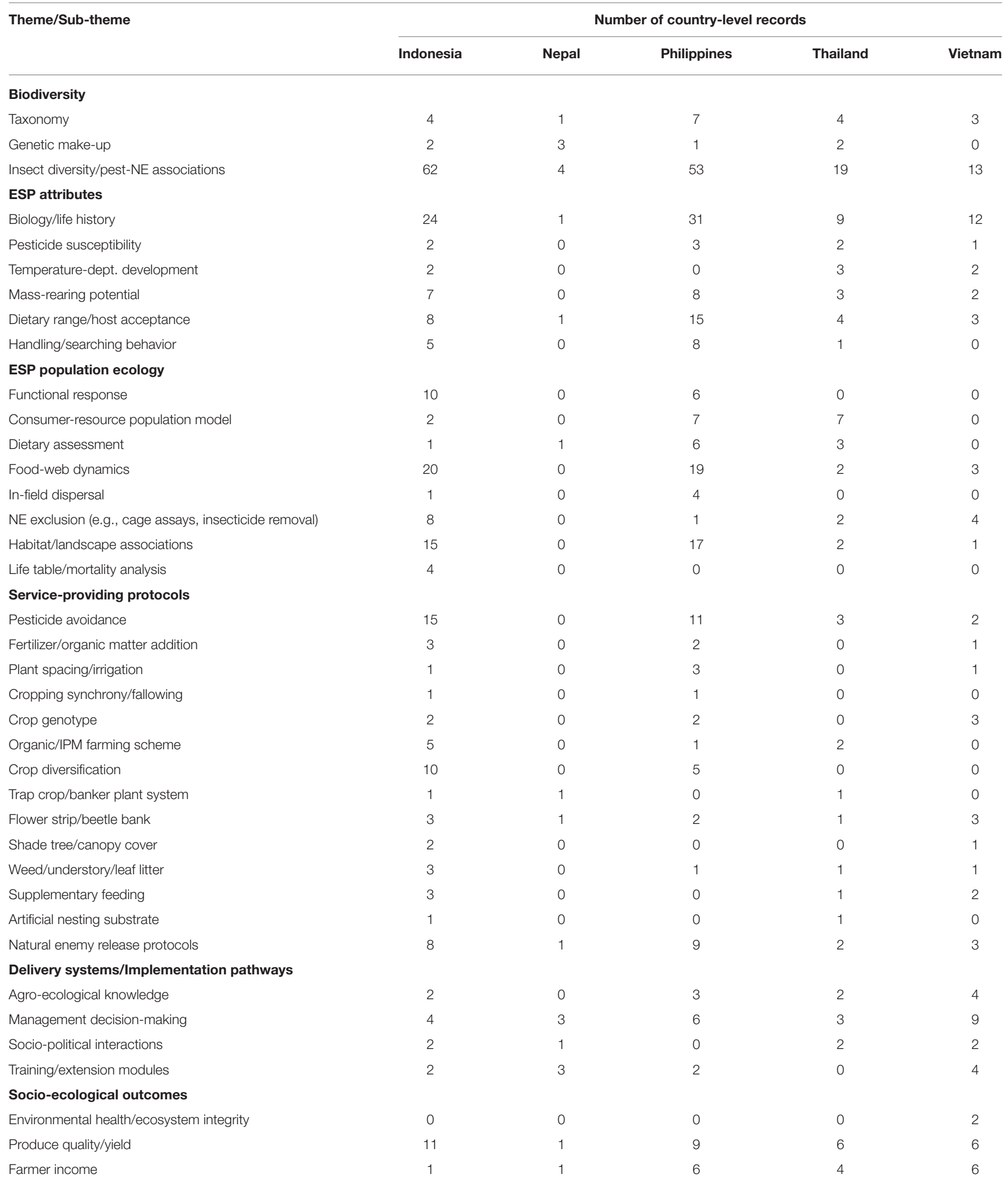

For each theme, sub-themes are listed that represent important research activities related to biological control. For each of five Asian countries, we list the number of scientific publications that have been generated per sub-theme, over a 50-year time frame. 
approach (Coll and Wajnberg, 2017), no pathways were drawn for individual crop $\times$ pest systems.

\section{RESULTS}

Queries resulted in a total of 430 scientific publications, covering field studies (264), laboratory assays (118), reviews and management recommendations (34), farmer surveys (15), theoretical concepts and modeling exercises (14), and green- or screenhouse assays (9). Most records were obtained for Indonesia (159) and the Philippines (138), while for Nepal, Thailand, and Vietnam a respective 16,62 , and 54 publications were collated. A total of 144 publications covered cereals and other graminoids (112 of which including rice), while other well-researched crops were vegetables (86 literature records, 36 of which cruciferous plants such as cabbage or broccoli), orchard crops (66) and oilseed crops (42). Crop focus within each country differed substantially, with $52 \%$ of publications from the Philippines addressing cereals (Figure 1). With a first record dating back to 1976 , literature output has risen over time with individual countries currently generating 10-87 publications per decade (Figure 1).

Resource items covered 11 different invertebrate orders and 69 families, with 159 organisms reported at the species-level (Figure 2). Most literature records were recovered for Hemiptera (152) and Lepidoptera (138); at the family level, Dephacidae,
Cicadellidae (Hemiptera), and Agromyzidae (Diptera) were covered in a total of 62,46 , and 38 publications, respectively. Scientific attention was equally given to consumer organisms, with a respective 163,173 , and 85 publications reporting on either parasitoids, predators or both trophic guilds. Consumer organisms belonged to 18 different class- or order-level taxa (Figure 2) and 103 families. Most records were recovered for Hymenoptera (224) and Coleoptera (66); at the family level, Coccinellidae, Eulophidae, and Braconidae featured in 62, 56, and 55 publications, respectively. At the species level, resource organisms that were well-featured included the rice brown planthopper Nilaparvata lugens (37 records), the cruciferous pest Plutella xylostella (24), and the Asian corn borer Ostrinia furnacalis (16). For consumer organisms, ample scientific attention was given to the mirid bug Cyrtorhinus lividipennis (14), the leafminer parasitoid Hemiptarsenus varicornis (13), and the weaver ant Oecophylla smaragdina in orchard systems (13). Resource items comprised both native pests such as $N$. lugens or O. furnacalis and invasive pests, e.g., P. xylostella, the coconut hispid Brontispa longissima or the cassava mealybug Phenacoccus manihoti. Hence, biological control interventions included the use of endemic species in conservation (e.g., O. smaragdina) or augmentation (e.g., the predatory earwig Euborellia annulipes) schemes as well as a scientifically guided introduction of exotic natural enemies (often paired with augmentative releases) such as Diadegma semiclausum and Cotesia plutellae against P. xylostella.

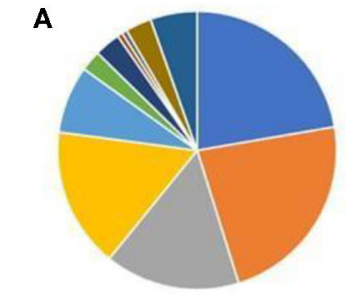

B
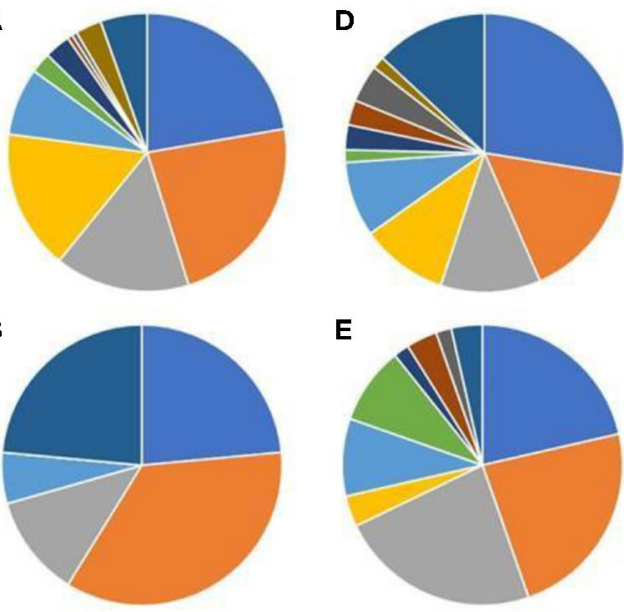

E

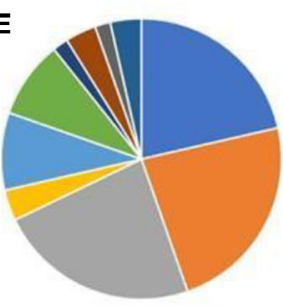

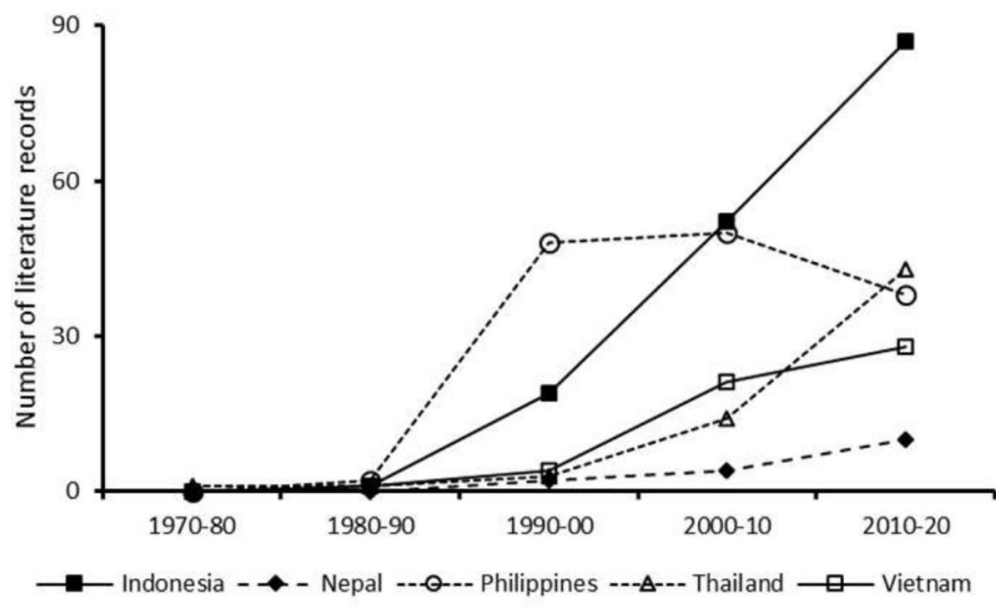

c

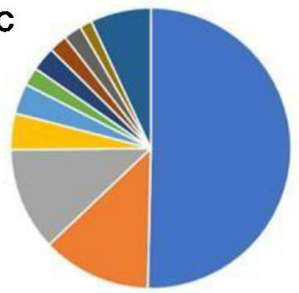

m orchard crops

= leguminous

- ornamental plants

w spices, herbs \& medicinal plants $=$ unspecified

FIGURE 1 | Temporal and commodity-specific trends in biological control science for selected Asia countries, as determined through systematic literature searches. The left panel comprises pie charts that reflect the relative scientific attention to different classes of agricultural commodities for Indonesia (A), Nepal (B), Philippines (C), Thailand (D), and Vietnam (E). The right panel depicts interdecadal trends in the number of scientific publications covering biological control, for each of the above countries. Crop classifications are based on the United Nations Food and Agriculture Organization, UN-FAO. 


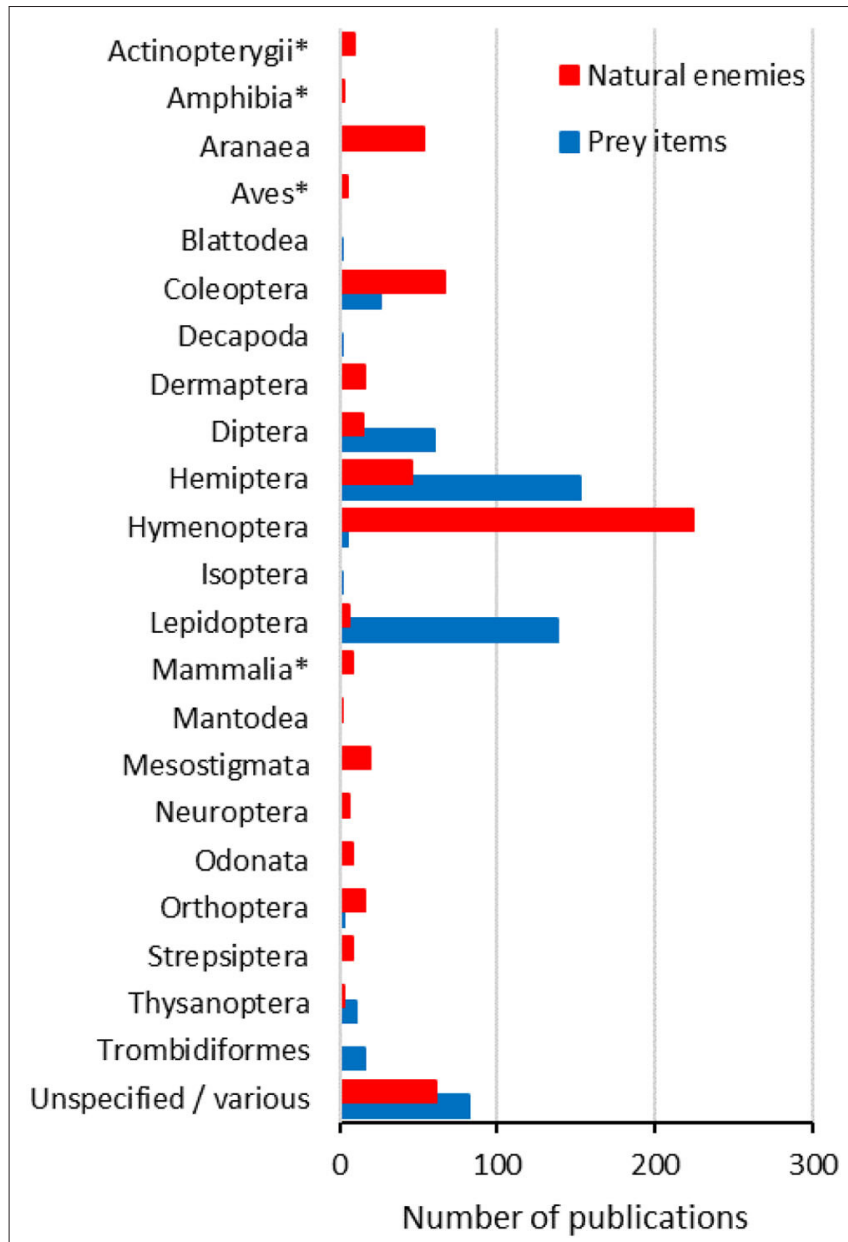

FIGURE 2 | Comparative extent of taxon-level scientific attention to prey items (e.g., herbivorous pests) and natural enemies. Bars represent the number of scientific publications covering a given taxon. Taxa include either consumer (i.e., natural enemy) or resource (i.e., prey) items. Taxa comprise different invertebrate orders within the phylum Arthropoda, while those with an asterisk belong to the phylum Vertebrata.
Along the six-step, outcome-oriented impact pathway, 168 (out of 430) publications covered the discovery and description of biodiversity in local ecosystems (Figures 3, 4; Table 1). Lesser degrees of scientific attention were given to assess ESP attributes and population ecology, with up to 24-31 studies per country covering ESP biology and life history and up to 15 studies addressing host range and feeding patterns (Table 1). ESP population ecology was well-covered in Indonesia and the Philippines, with ample attention given to measuring functional response, characterizing in-field population dynamics or quantifying habitat- and landscape-level associations. Myriad experimental methods were employed to quantitatively assess natural enemies' interaction with resource items, with up to 4, 6, and 8 studies/country, respectively involving life table analysis, exclusion techniques and dietary assessment e.g., using behavioral observations or stomach flushing of fish

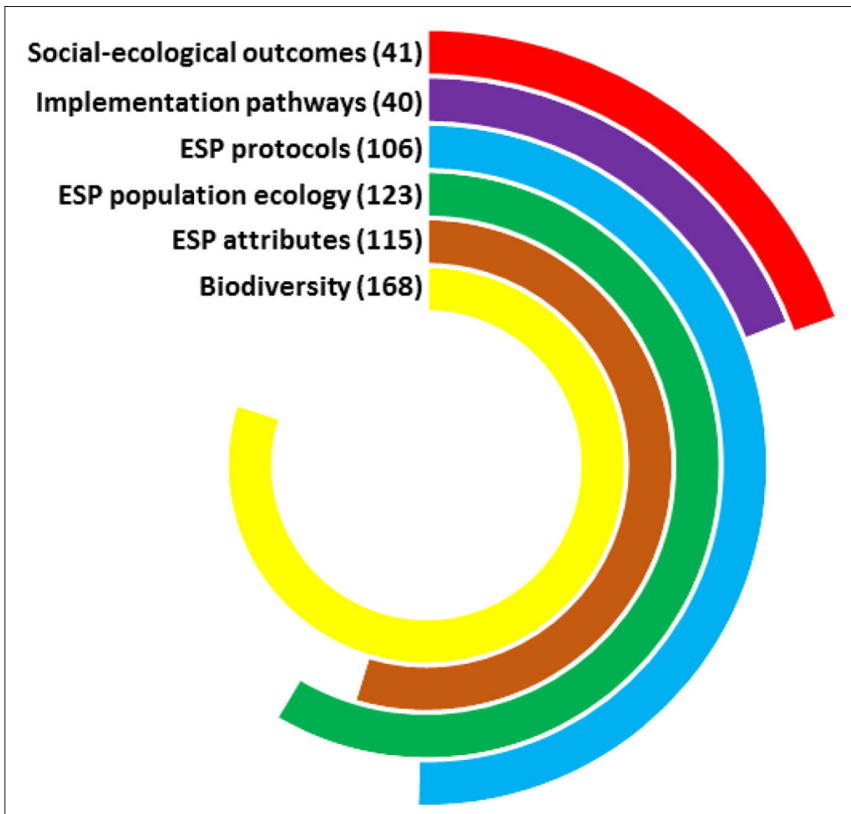

FIGURE 3 | Progress of biological control science along a six-step, outcome-oriented "impact pathway" for all Asian countries over a 50-year time frame. Within the concentric donut chart, the exact circumference of each loop mirrors the relative amount of scientific attention to a given research theme. For a given theme, the respective amount of scientific attention is expressed by the number of publications covering this theme. Themes include the measurement of farm-level biodiversity (inner-most circle) or a characterization of key attributes of ecosystem-service providers (ESP), to ultimately culminate in the envisioned social-ecological outcomes. Social-ecological outcomes also include crop yield (i.e., primary productivity) as imperfect proxy of farmer income or farm-level revenue, both important in achieving agro-ecological outcomes.

and frogs. A total of 106 publications reported the fieldlevel evaluation of service-providing protocols (SPPs), usually involving manipulative assays to record the impact of specific management changes (i.e., up to 15 publications/country reporting pesticide avoidance or fertilizer addition), habitat manipulations (i.e., up to ten records/country covering crop diversification or flower strips) or natural enemy additions. Work in Thailand and Indonesia assessed artificial nesting substrates for the predator ants O. smaragdina and Dolichoderus thoracicus in cocoa and fruit orchards (Anshary and Pasaru, 2008; Offenberg, 2014). Many SPP evaluation studies involved the concurrent in-field monitoring of pest and natural enemy populations but did not entail additional manipulative assays to quantify strength of biological control.

Comparatively low amounts of scientific attention were given to themes further along the $\mathrm{BC}$ impact pathway such as delivery systems, implementation pathways, and socio-economic outcomes (Figure 3; Table 1). In the former theme, most publications (25) either covered scientists' characterization of farmer management practices and decision-making processes underlying the uptake of biological control or outlined pest management recommendations - the latter routinely tailored to scientists instead of to farmer end-users. Publications 


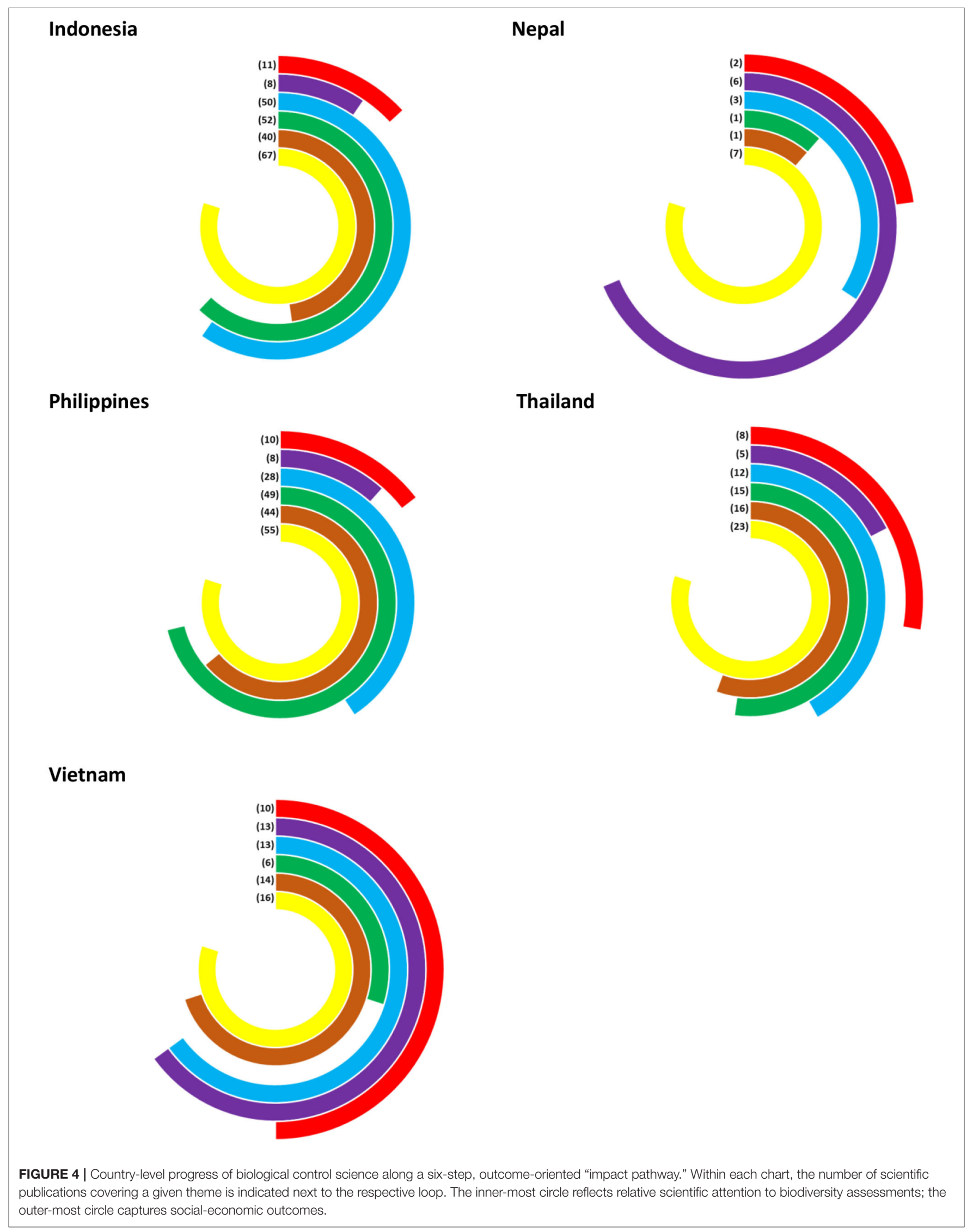


covering farmers' (agro-ecological) knowledge were equally limited in geographic and commodity scope, with 3-4 records each (out of 11) on Philippine rice or fruit orchards in Vietnam's Mekong Delta (but see Yanuwiadi, 2017). In terms of outcomes, though 33 different publications reported changes in crop yield, farm-level agricultural output or indices of product quality (i.e., sweetness, juiciness or oranges; Barzman et al., 1996), as few as 18 studies reported true socioeconomic outcome measures such as farmer income. Also, social-ecological outcomes of biological control were only assessed in a comparatively small complement of cropping systems, i.e., fruit orchards, cassava, rice, and cruciferous crops impacted by the diamondback-moth P. xylostella. This lack of studies concerning socio-economic and socio-ecological parameters reflects a global challenge to reduce the gap between science and practice (Kleijn et al., 2019; Shields et al., 2019; González-Chang et al., 2020).
Biological control science in each of the five Asian countries progressed to variable extent along our six-step impact pathway (Figure 3). While the bulk of scientific publications from Indonesia or the Philippines covered the first three or four "basic" themes, reverse patterns were observed for Nepal. In Vietnam, scientific attention evenly covered the entire pathway, though crop and geographic focus for themes five and six was largely confined to rice, cassava, and fruit orchards (the latter in the Mekong Delta). Conversely, when considering crop-specific impact pathways, we recorded a lagging scientific attention to themes further along the pathway for grain cereals and oilseed crops such as coconut, oil palm, or soybean (Figure 5). For cereal crops such as rice, though ample scientific attention was given to the description of biodiversity, in-field population ecology and SPP validation, comparatively little advances were made in characterizing core attributes of ESPs, such as natural enemy communities and their environmental interactions.

\section{Cereals \& graminoids}

\section{Oilseed crops}

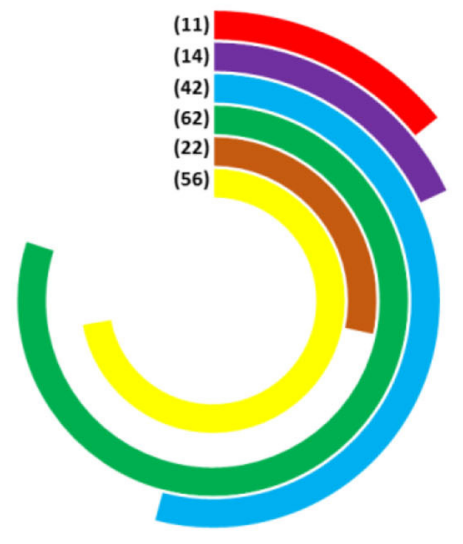

Orchard crops

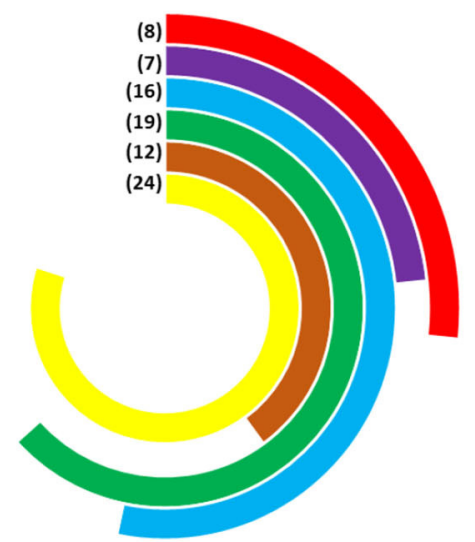

Vegetables

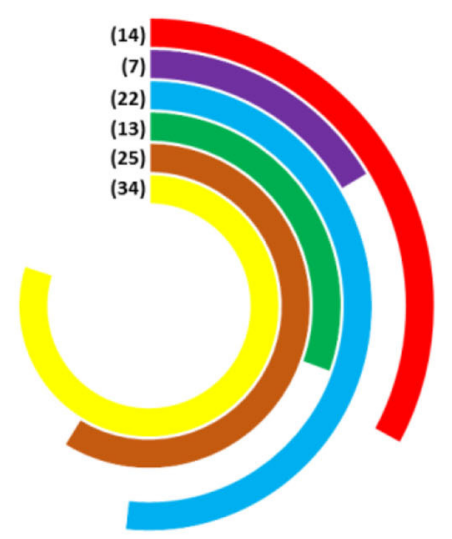

FIGURE 5 | Commodity-specific progress of biological control science along a 6-step, outcome-oriented "impact pathway." Within the concentric donut chart, the exact number of scientific publications covering a given theme is indicated next to the respective loop. Patterns are plotted for all five Asian countries, over a 50-year time frame. The category of "cereals and graminoids" includes rice, while "oilseed crops" covers coconut, oil palm, and soybean. Crop classifications are based on the United Nations Food and Agriculture Organization, UN-FAO. 


\section{DISCUSSION}

To mitigate the externalities of conventional, high-input agriculture, and to keep global food systems within environmental limits, transformative change -if not a "Greener Revolution" - must be pursued in current farming systems (Tilman, 1998; Poore and Nemecek, 2018; Pretty et al., 2018; Willett et al., 2019). Such transformation can be enabled through applied ecology (Bommarco et al., 2013), released through social science e.g., anthropology and economics (Hackmann et al., 2014; Naranjo et al., 2015) and brought about hand-in-hand with farmers and food producers (Altieri, 2004; MacMillan and Benton, 2014; Zhang et al., 2016; Mills et al., 2017; González-Chang et al., 2020). Biodiversity is the cornerstone of such revolution, featuring prominently in legume-based diversification and other practices to regenerate soil health (Snapp et al., 2010; LaCanne and Lundgren, 2018) or in the fieldlevel conservation of biological control (BC) organisms (Dainese et al., 2019). Yet, in order for BC to achieve its full potential, scientists need to measure the correct variables and address the right questions (Geertsema et al., 2016; Jeanneret et al., 2016; Chaplin-Kramer et al., 2019). Here, fragmented research agendas, pest-centric approaches and disciplinary boundaries prevent the necessary holistic perspectives, obstruct collaboration and impede defining effective, integrative "action-oriented" solutions (Brondizio et al., 2016; DeFries and Nagendra, 2017; Yletyinen et al., 2019). Our "Humboldtian" perspective offers a structured quantification of the progress BC science has made in translating on-farm biodiversity into concrete, verifiable socio-ecological outcomes.

Our work complements earlier "culturomics" assessments of biodiversity and ecosystem services research (Hines et al., 2019) while drawing on recent advances in agricultural innovation science, e.g., transdisciplinary weed research (Jordan et al., 2016; Wigboldus et al., 2016). By doing so, this paper transcends the traditional "mono-disciplinary" field of applied insect ecologyin which, over the past century, innumerable dedicated scientists have laid a solid foundation for the technical facets of pest management science and biological control (e.g., Barbosa, 1998; Fisher et al., 1999; Landis et al., 2000; Gurr et al., 2017; Heimpel and Mills, 2017). Instead, through extensive literature searches and standardized analyses, we captured all BC published work irrespective of disciplinary boundaries, thus accounting for scholarly outputs that comprised biodiversity, ecological processes or farm management interventions but also decisionmaking among different stakeholders (e.g., scientists, farmers, extension personnel) at varying spatial scales (e.g., in-field, farm, agro-landscape, region). As such, we gain unprecedented insights into the extent to which BC innovations-under given Asian geographical or cropping system contexts-are "fit for purpose," technically ready to be used at scale and can thus contribute to agro-ecological transitions in agri-food systems (El Bilali, 2019; González-Chang et al., 2020; Sartas et al., 2020). Based upon our analyses, several BC interventions are ready for scaling e.g., farm- and landscape-level interventions to enhance conservation $\mathrm{BC}$ in rice (e.g., Westphal et al., 2015; Horgan et al., 2019), the century-long use of the weaver ant $O$. smaragdina in fruit orchards (Van Mele and Cuc, 2000), or the integrated use of Bacillus thuringiensis $(\mathrm{Bt})$ and C. plutellae or Diadegma insulare parasitoid releases in cruciferous crops.

Our assessment, though comprehensive and interdisciplinary, is not without caveats. First, published work by national scientists in either domestic or Asia-regional academic journals was rarely picked up by WoS and Dimensions search engines. This data gap was filled to varying extent by running further in-country searches, e.g., covering national library databases. Second, though biological control constitutes a core component of integrated pest management (IPM), it is only intermittently listed as such in abstracts of IPM-related papers. Hence, publications that covered e.g., IPM farmer field schools and community IPM (Röling and Van De Fliert, 1994; Matteson, 2000; Pontius, 2002) outlined how participatory extension methods helped farmers identify and value natural enemies but often did not explicitly cover biological control. Hence, some of these papers equally were not included in our assessments. Third, we observe uneven reporting of BC socio-ecological outcomes between countries, crop $x$ pest systems and scientific disciplines. While natural scientists sustain a steady publication output covering in-field dynamics or BC ecological outcomes (Cock et al., 2016), published expost assessments of $\mathrm{BC}$ interventions by social scientists remain rare-especially in Asian countries (Onstad and Knolhoff, 2009; Naranjo et al., 2015; Shields et al., 2019; Upadhyay et al., 2020). We recognize that future endeavors must account for the above issues, in order to paint a complete picture of BC science (and its resulting socio-ecological achievements).

Biodiversity-based interventions pay off; though only $4.2 \%$ of all $\mathrm{BC}$ publications found here reported monetary impacts, farmlevel impacts are often substantial. One third of these studies specifically reported on the in-field conservation or augmentative release of C. plutellae and D. insulare wasps in cruciferous crops, which raised farmer income by up to $78 \%$ (Morallo-Rejesus et al., 2000) and cut pesticide expenditure with US\$133-513/ha in various settings (Nga and Kumar, 2008; Table 2). Considering how $59-100 \%$ of farmers in Vietnam, Cambodia or Laos overuse pesticides at values up to $\$ 262 / \mathrm{ha} /$ cycle in leafy brassicas, BC constitutes a viable, practicable alternative to pesticide-based schemes. By lifting financial solvency of farming households, BC may even allow for incremental spending on consumer goods and potentially feed forward into the national economy (Haggblade et al., 2007). Farm-level monetary benefits however are not only restricted to cruciferous vegetables. In sugarcane, planted on $>2.7$ million hectares in Southeast Asia, scheduled releases of the larval parasitoid Cotesia flavipes raised profit by a staggering 208-315\% (Maneerat et al., 2017). Simulation analyses further revealed how inoculative releases of the encyrtid Anagyrus lopezi may bring up to $\$ 1,714 /$ ha increased revenue for cassava producers (Aekthong and Rattanakul, 2019), while conservation of the wrinkle-lipped bat Tadarida plicata annually yields US $\$ 1.2$ million in dividends for Thailand's national economy (Wanger et al., 2014). This kind of economic valuation of ecosystem services is crucial -though not sufficient- to allow broader societal recognition, raise its stock with key stakeholders and ultimately attain outcomes at scale (Kronenberg, 2014; Naranjo et al., 2015). Considering how just 18 studies have attempted to value BC 
TABLE 2 | Concrete monetary impacts of historic biological control interventions.

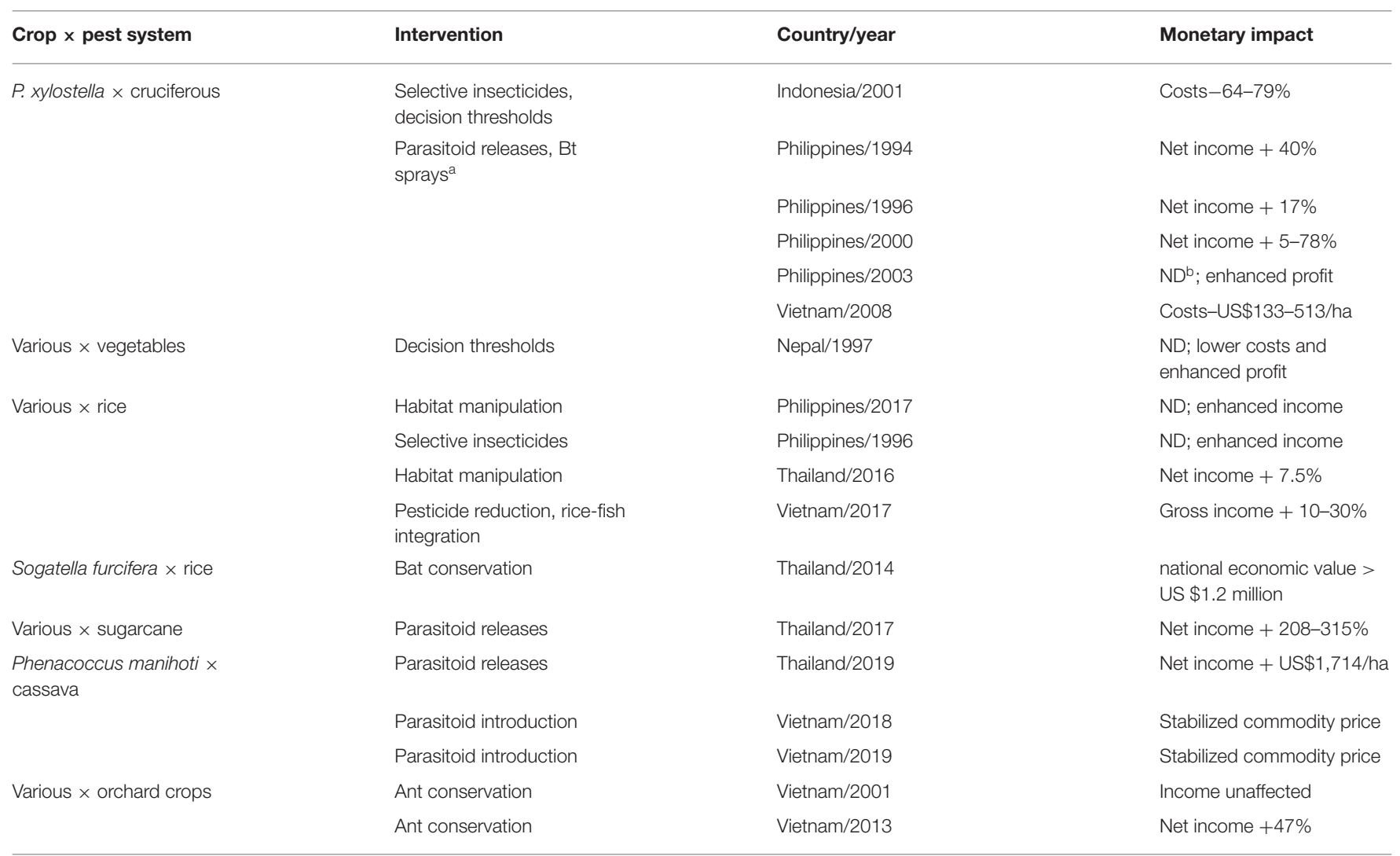

Records cover all three subdisciplines of biological control (i.e., classical, augmentation, conservation) and are limited to those featured in the scientific literature, for five selected Asian countries over a 50-year time frame.

${ }^{a} B t, B$. thuringiensis; IGR: insect growth regulator.

${ }^{b} N D$, not determined.

services across Asian agro-landscapes over a 50-year timeframe, a step-change is clearly needed.

By assigning published work to specific steps along the outcome-oriented "impact pathway," regional progress in $\mathrm{BC}$ science became visible. Invertebrate taxonomy surely needs more "boots on the ground" in the tropics (Wilson, 2017), yet $39 \%$ of publication output covered the (morphological, molecular) identification of on-farm biota and entailed the description of pest $\times$ natural enemy communities in Asian agroecosystems. This emphasis on biodiversity discovery/description is manifest across crops and geographies (Figures 2, 3) and catalyzed "downstream" applied ecology research across core domains-except for Nepal. For cereals and graminoids, the comparatively minor attention to ESP attributes is partially counterweighted by trials in other countries (e.g., on riceinhabiting parasitoids and predators; Zhu et al., 2014) and extensive field-level community ecology and SPP assays. Limited attention was paid to life history trials on plant-derived, nonprey foods such as pollen (five studies), floral nectar (1), or honey as a substitute (6) (Lundgren, 2009); even though these assays underpin the development of effective SPPs (Gurr et al., 2017). Similarly, to quantitatively assess BC services, novel methods such as video surveillance, serological assays, or molecular gut content approaches have not been used (Phillips and Gardiner, 2015). Across cropping systems, studies were performed using a range of baselines, currencies and spatial scales (Hines et al., 2019). As such, ESP populations were studied along pesticide-use, soil fertility or land-use intensity gradients (Basedow, 1993; Klein et al., 2002; Wyckhuys et al., 2017). While field- or farm-level studies were common across settings, studies at broader spatial scale were primarily carried out in cocoa- or rice-based systems in Indonesia and the Philippines (Maas et al., 2013; Dominik et al., 2017). Aside from considering soil-based SPPs in six studies (Table 1), virtually no attention is given to the interplay between soildwelling and above-ground biota; a presumed driver of biological control (Veen et al., 2019). The shape of the commodityspecific impact pathways mirrors the BC subdisciplines that are primarily pursued. In oilseed crops such as coconut and oil palm, interventions targeted invasive pests such as $B$. longissima (6), Aspidiotus rigidus (4), or Raoiella indica (2), and primarily entailed biology and ecology studies, followed by guided releases of candidate natural enemies. Farmers and land managers were routinely bypassed and impact assessments were few (Andrews et al., 1992; Geertsema et al., 2016; Barratt et al., 2018), thus resulting in pathways in which categories five and six were critically under-represented. Conversely, for orchard and vegetable systems, BC science covered more "downstream" 
themes though this often resulted from the devoted work of few individual scientists or single institutions (e.g., Van Mele and Cuc, 2000).

Our exercise helps strategize science to fill key research gaps and to devise proper SPP protocols, thus improving the odds of achieving concrete outcomes. Out of the myriad ways to accelerate BC uptake across Asian agri-food systems, we spotlight three clear opportunities. First, predatory mites constituted the focus of 20 (largely laboratory-based) studies, with new species continuing to be described (Kreiter et al., 2020) while local farmers are still unaware about their existence and BC role (Wyckhuys et al., 2019). Further taxonomic surveys are warranted in Asia's biodiversity-rich agro-ecosystems, but applied socio-ecological research is also needed to ensure that conservation or augmentation BC with Phytoseiid mites is "fit for purpose" and properly valued by end-users. Second, Tephritid fruit flies are key pests of multiple fruit and vegetable crops, yet were only covered in $1.6 \%$ of BC publications. Given how fruit flies are vulnerable to predation during the larval and pupal stages (Bateman, 1972), generalist soil-dwelling predators can greatly enhance Tephritid mortality in orchards (Albertini et al., 2018). In this sense, the use of molecular tools is a promising strategy to unveil trophic interactions (González-Chang et al., 2016), identify key fruit fly predators (Albertini et al., 2018), and ultimately formulate suitable locally-adapted SPP. Third, invasive pests put a major drag on Asian economies (Nghiem et al., 2013) and pest targets have been prioritized for BC (Waterhouse, 1998). To exploit $\mathrm{BC}$ for invasive pest management, all steps along the "impact pathway," i.e., from biodiversity discovery in foreign exploration to an on-farm valuation of appropriate SPP such as release rates and densities (Shea et al., 2002), are important and can help disseminate BC knowledge amongst farmers (GonzálezChang et al., 2020). A proper ex-ante assessment of the dietary breadth of candidate natural enemies (e.g., as in-vitro description of ESP attributes) is essential to account for eventual risks, ensure biosafety and carefully anticipate eventual non-target impacts (Barratt et al., 2010; Barratt, 2011).

Our work rekindles the long-standing interest in systems thinking for pest management (e.g., Lewis et al., 1997),

\section{REFERENCES}

Acevedo, M. F., Harvey, D. R., and Palis, F. G. (2018). Food security and the environment: interdisciplinary research to increase productivity while exercising environmental conservation. Glob. Food Secur. 16, 127-132. doi: 10.1016/j.gfs.2018.01.001

Aekthong, S., and Rattanakul, C. (2019). Investigating the use of wasps Anagyrus lopezi as a biological control agent for cassava mealybugs: modeling and simulation. Adv. Dif. Equations 2019:237. doi: 10.1186/s13662-0192176-3

Albertini, A., Marchi, S., Ratti, C., Burgio, G., Petacchi, R., and Magagnoli, S. (2018). Bactrocera oleae pupae predation by Ocypus olens detected by molecular gut content analysis. BioControl 63, 227-239. doi: 10.1007/s10526-01 7-9860-6

Alston, J. M., and Pardey, P. G. (2014). Agriculture in the global economy. J. Econ. Perspect. 28, 121-146. doi: 10.1257/jep.28.1.121

Altieri, M. A. (1984). Pest-management technologies for peasants: a farming systems approach. Crop Protect. 3, 87-94. doi: 10.1016/0261-2194(84)90010-3 accentuates how BC science touches upon the multi-faceted socio-ecological dimensions of Asian agriculture, and draws science-based trajectories to enhance the likelihood of attaining concrete socio-ecological outcomes. As a true pioneer in systems thinking, Alexander von Humboldt straddled scientific disciplines such as ecology, climatology, and geosciences to pursue ground-breaking theories that shaped much of our current scientific understanding of natural phenomena (Jackson, 2009; Wulf, 2015). More than 200 years ago, Humboldt realized how human-mediated land-use change can disrupt the delicate ecological balance of nature and ultimately impact societal wellbeing. As such, Humboldt inspired our effort to devise strategies that harness biodiversity in farming systems and thereby realize the promise of insect biological control. Our "Humboldtian" perspective foment a transformational change in Asian agri-food systems, ultimately pursuing $\mathrm{ABB}$ farming systems that foster human well-being without sacrificing nature.

\section{DATA AVAILABILITY STATEMENT}

The raw data supporting the conclusions of this article will be made available by the authors, without undue reservation.

\section{AUTHOR CONTRIBUTIONS}

KW and MG-C conceived the manuscript and organized the literature review process. All authors contributed to writing this article.

\section{ACKNOWLEDGMENTS}

The development of this manuscript and its underlying research received no noteworthy funding. In Thailand, Amonporn Kunaphan, Nantanat Pinsri, Nongnuch Changsee, and Woranad Khokyen Suwannarat Sonvijit helped to compile the necessary literature records. MG-C would like to acknowledge fondo semilla 2018 from Universidad de Aysén for its continuous support.

Altieri, M. A. (2004). Linking ecologists and traditional farmers in the search for sustainable agriculture. Front. Ecol. Environ. 2, 35-42. doi: 10.1890/1540-9295(2004)0020035:LEATFI2.0.CO;2

Andrews, K. L., Bentley, J. W., and Cave, R. D. (1992). Enhancing biological control's contributions to integrated pest management through appropriate levels of farmer participation. Florida Entomol. 75, 429-439. doi: $10.2307 / 3496124$

Anshary, A., and Pasaru, F. (2008). Mass rearing technique and predator application of Dolichoderus thoracicus for cacao pod borer (Conopomorpha cramerella) control in smallholder plantations. J. Agroland 15, 278-287.

Bale, J. S., Van Lenteren, J. C., and Bigler, F. (2008). Biological control and sustainable food production. Philos. Trans. R. Soc. B Biol. Sci. 363, 761-776. doi: $10.1098 /$ rstb.2007.2182

Barbosa, P. A. (Ed.). (1998). Conservation Biological Control. San Diego, CA: Elsevier.

Barratt, B. I. P. (2011). Assessing safety of biological control introductions. CAB Rev. Perspect. Agric. Vet. Sci. Nutr. Nat. Res. 6, 1-12. doi: 10.1079/PAVSNNR20116042 
Barratt, B. I. P., Howarth, F. G., Withers, T. M., Kean, J. M., and Ridley, G. S. (2010). Progress in risk assessment for classical biological control. Biol. Control 52, 245-254. doi: 10.1016/j.biocontrol.2009.02.012

Barratt, B. I. P., Moran, V. C., Bigler, F., and Van Lenteren, J. C. (2018). The status of biological control and recommendations for improving uptake for the future. BioControl 63, 155-167. doi: 10.1007/s10526-017-9831-y

Barzman, M. S., Mills, N. J., and Cuc, N. T. T. (1996). Traditional knowledge and rationale for weaver ant husbandry in the mekong delta of Vietnam. Agric. Hum. Values 13, 2-9. doi: 10.1007/BF01530519

Basedow, T. (1993). Predatory arthropods in cabbage terraces under different conditions in the cordillera region of Luzon, Philippines. Bull. Entomol. Res. 83, 313-319. doi: 10.1017/S0007485300029199

Bateman, M. A. (1972). The ecology of fruit flies. Annu. Rev. Entomol. 17, 493-518. doi: 10.1146/annurev.en.17.010172.002425

Bommarco, R., Kleijn, D., and Potts, S. G. (2013). Ecological intensification: harnessing ecosystem services for food security. Trends Ecol. Evol. 28, 230-238. doi: 10.1016/j.tree.2012.10.012

Bottrell, D. G., and Schoenly, K. G. (2012). Resurrecting the ghost of green revolutions past: the brown planthopper as a recurring threat to highyielding rice production in tropical Asia. J. Asia Pac. Entomol. 15, 122-140. doi: 10.1016/j.aspen.2011.09.004

Brainerd, E., and Menon, N. (2014). Seasonal effects of water quality: the hidden costs of the green revolution to infant and child health in India. J. Dev. Econ. 107, 49-64. doi: 10.1016/j.jdeveco.2013.11.004

Brondizio, E. S., O’brien, K., Bai, X., Biermann, F., Steffen, W., Berkhout, F., et al. (2016). Re-conceptualizing the anthropocene: a call for collaboration. Glob. Environ. Change 39, 318-327. doi: 10.1016/j.gloenvcha.2016. 02.006

Chaplin-Kramer, R., O’Rourke, M., Zhang, W., Robinson, B., Schellhorn, N., Gratton, C., et al. (2019). Measuring what matters: actionable information for conservation biocontrol in multifunctional landscapes. Front. Sustain. Food Syst. 3:60. doi: 10.3389/fsufs.2019.00060

Cock, M. J., Murphy, S. T., Kairo, M. T., Thompson, E., Murphy, R. J., and Francis, A. W. (2016). Trends in the classical biological control of insect pests by insects: an update of the BIOCAT database. BioControl 61, 349-363. doi: $10.1007 /$ s10526-016-9726-3

Coll, M., and Wajnberg, E. (2017). "Environmental pest management: a call to shift from a pest-centric to a system-centric approach," in Environmental Pest Management: Challenges for Agronomists, Ecologists, Economists and Policymakers, eds M. Coll, and E. Wajnberg (Hoboken, NJ: Wiley), 1-18. doi: 10.1002/9781119255574.ch1

Daily, G. C., Polasky, S., Goldstein, J., Kareiva, P. M., Mooney, H. A., Pejchar, L., et al. (2009). Ecosystem services in decision making: time to deliver. Front. Ecol. Environ. 7, 21-28. doi: 10.1890/080025

Dainese, M., Martin, E., Aizen, M., Albrecht, M., Bartomeus, I., Bommarco, R., et al. (2019). A global synthesis reveals biodiversity-mediated benefits for crop production. Sci. Adv. 5:eaax0121. doi: 10.1126/sciadv.aax0121

DeBach, P., and Rosen, D. (1991). Biological Control by Natural Enemies. Cambridge, UK: Cambridge University Press. Available online at: https://www. thesolutionsjournal.com/article/landscape-features-improve-pest-controlagriculture/

DeFries, R., and Nagendra, H. (2017). Ecosystem management as a wicked problem. Science 356, 265-270. doi: 10.1126/science.aal1950

Dirzo, R., Young, H. S., Galetti, M., Ceballos, G., Isaac, N. J., and Collen, B. (2014). Defaunation in the anthropocene. Science 345, 401-406. doi: $10.1126 /$ science. 1251817

Dominik, C., Seppelt, R., Horgan, F., Marquez, L., Settele, J., and Vaclavik, T. (2017). Regional-scale effects override the influence of fine-scale landscape heterogeneity on rice arthropod communities. Agric. Ecosyst. Environ. 246, 269-278. doi: 10.1016/j.agee.2017.06.011

El Bilali, H. (2019). The multi-level perspective in research on sustainability transitions in agriculture and food systems: a systematic review. Agriculture 9:74. doi: 10.3390/agriculture9040074

Fisher, T. W., Bellows, T. S., Caltagirone, L. E., Dahlsten, D. L., Huffaker, C. B., and Gordh, G. (Eds.). (1999). Handbook of Biological Control: Principles and Applications of Biological Control. San Diego, CA: Elsevier.

Geertsema, W., Rossing, W. A., Landis, D. A., Bianchi, F. J., Van Rijn, P. C., Schaminée, J. H., et al. (2016). Actionable knowledge for ecological intensification of agriculture. Front. Ecol. Environ. 14, 209-216. doi: $10.1002 /$ fee. 1258

González-Chang, M., Wratten, S. D., Lefort, M. C., and Boyer, S. (2016). Food webs and biological control: a review of molecular tools used to reveal trophic interactions in agricultural systems. Food Webs 9, 4-11. doi: 10.1016/j.fooweb.2016.04.003

González-Chang, M., Wratten, S. D., Shields, M. W., Costanza, R., Dainese, M., Gurr, G., et al. (2020). Understanding the pathways from biodiversity to agro-ecological outcomes: a new, interactive approach. Agric. Ecosyst. Environ. 301:107053. doi: 10.1016/j.agee.2020.107053

Gorman, K., Liu, Z., Denholm, I., Brüggen, K. U., and Nauen, R. (2008). Neonicotinoid resistance in rice brown planthopper, Nilaparvata lugens. Pest Manag. Sci. 64, 1122-1125. doi: 10.1002/ps.1635

Gurr, G. M., Lu, Z., Zheng, X., Xu, H., Zhu, P., Chen, G., et al. (2016). Multicountry evidence that crop diversification promotes ecological intensification of agriculture. Nat. Plants 2, 1-4. doi: 10.1038/nplants.2016.14

Gurr, G. M., Wratten, S. D., Landis, D. A., and You, M. (2017). Habitat management to suppress pest populations: progress and prospects. Annu. Rev. Entomol. 62, 91-109. doi: 10.1146/annurev-ento-031616-035050

Hackmann, H., Moser, S. C., and Clair, A. L. S. (2014). The social heart of global environmental change. Nat. Clim. Change 4, 653-655. doi: 10.1038/nclimate2320

Haggblade, S., Hazell, P. B., Dorosh, P. A. (2007). "Sectoral growth linkages between agriculture and the rural nonfarm economy," in Transforming the Rural Nonfarm Economy: Opportunities and Threats in the Developing World, eds S. Haggblade, P. B. R. Hazell, and T. Reardon (Baltimore, MD: Johns Hopkins University Press), 141-182.

Heimpel, G. E., and Mills, N. J. (2017). Biological Control. Cambridge, UK: Cambridge University Press. doi: 10.1017/9781139029117

Hines, J., Ebeling, A., Barnes, A. D., Brose, U., Scherber, C., Scheu, S., et al. (2019). "Mapping change in biodiversity and ecosystem function research: food webs foster integration of experiments and science policy," in Mechanisms Underlying the Relationship Between Biodiversity and Ecosystem Function, ed N. Eisenhauer (San Diego, CA: Academic Press), 297-322. doi: 10.1016/bs.aecr.2019.06.008

Horgan, F. G., Crisol Martínez, E., Stuart, A. M., Bernal, C. C., de Cima Martín, E. Almazan, M. L. P., et al. (2019). Effects of vegetation strips, fertilizer levels and varietal resistance on the integrated management of arthropod biodiversity in a tropical rice ecosystem. Insects 10:328. doi: 10.3390/insects10100328

Isbell, F., Gonzalez, A., Loreau, M., Cowles, J., Díaz, S., Hector, A., et al. (2017). Linking the influence and dependence of people on biodiversity across scales. Nature 546, 65-72. doi: 10.1038/nature22899

Jackson, S. T. (2009). Alexander von humboldt and the general physics of the Earth. Science 324, 596-597. doi: 10.1126/science.1171659

Jeanneret, P., Begg, G., Gosme, M., Alomar, O., Reubens, B., Baudry, J., et al. (2016). Landscape features to improve pest control in agriculture. Solutions 7, 48-57. Available online at: https://www.thesolutionsjournal.com/article/ landscape-features-improve-pest-control-agriculture/

Jepson, P. C., Murray, K., Bach, O., Bonilla, M. A., and Neumeister, L. (2020). Selection of pesticides to reduce human and environmental health risks: a global guideline and minimum pesticides list. Lancet Planet. Health 4, e56-e63. doi: 10.1016/S2542-5196(19)30266-9

Jordan, N., Schut, M., Graham, S., Barney, J. N., Childs, D. Z., Christensen, S., et al. (2016). Transdisciplinary weed research: new leverage on challenging weed problems? Weed Res. 56, 345-358. doi: 10.1111/wre. 12219

Jørgensen, P. S., Aktipis, A., Brown, Z., Carriere, Y., Downes, S., Dunn, R. R., et al. (2018). Antibiotic and pesticide susceptibility and the anthropocene operating space. Nat. Sustain. 1, 632-641. doi: 10.1038/s41893-018-0 164-3

Khan, S. A. R. (2019). The nexus between carbon emissions, poverty, economic growth, and logistics operations-empirical evidence from southeast Asian countries. Environ. Sci. Pollut. Res. 26, 13210-13220. doi: 10.1007/s11356-019-04829-4

Kleijn, D., Bommarco, R., Fijen, T. P. M., Garibaldi, L. A., Potts, S. G., and van der Putten, W. H. (2019). Ecological intensification: bridging the gap between science and practice. Trends Ecol. Evol. 34, 154-166. doi: $10.1016 /$ j.tree.2018.11.002 
Klein, A. M., Steffan-Dewenter, I., and Tscharntke, T. (2002). Predator-prey ratios on cocoa along a land-use gradient in Indonesia. Biodivers. Conserv. 11, 683-693. doi: 10.1023/A:1015548426672

Kreiter, S., Bopp, M. C., Douin, M., Duc, T. N., and Wyckhuys, K. A. G. (2020). Phytoseiidae of Vietnam (acari: mesostigmata) with description of a new species. Acarologia 60, 75-110. doi: 10.24349/acarologia/20204362

Kronenberg, J. (2014). What can the current debate on ecosystem services learn from the past? Lessons from economic ornithology. Geoforum 55, 164-177. doi: 10.1016/j.geoforum.2014.06.011

LaCanne, C. E., and Lundgren, J. G. (2018). Regenerative agriculture: merging farming and natural resource conservation profitably. PeerJ. 6:e4428. doi: $10.7717 /$ peerj. 4428

Landis, D. A., Wratten, S. D., and Gurr, G. M. (2000). Habitat management to conserve natural enemies of arthropod pests in agriculture. Annu. Rev. Entomol. 45, 175-201. doi: 10.1146/annurev.ento.45.1.175

Lewis, W. J., Van Lenteren, J. C., Phatak, S. C., and Tumlinson, J. H. (1997). A total system approach to sustainable pest management. Proc. Natl. Acad. Sci. U.S.A. 94, 12243-12248. doi: 10.1073/pnas.94.23.12243

Losey, J., and Vaughan, M. (2006). The economic value of ecological services provided by insects. BioScience 56, 311-323. doi: 10.1641/0006-3568(2006)56311:TEVOES2.0.CO;2

Lundgren, J. G. (2009). "Relationships of natural enemies and non-prey foods," in Progress in Biological Control, Vol. 7, (Dordrecht: Springer), 279-307. doi: 10.1007/978-1-4020-9235-0

Maas, B., Clough, Y., and Tscharntke, T. (2013). Bats and birds increase crop yield in tropical agroforestry landscapes. Ecol. Lett. 16, 1480-1487. doi: $10.1111 /$ ele. 12194

MacMillan, T., and Benton, T. G. (2014). Agriculture: engage farmers in research. Nat. News 509:25. doi: 10.1038/509025a

Maneerat, T., Uraichuen, S., and Suasaard, W. (2017). Economic impact of Cotesia flavipes (cameron) (hymenoptera: braconidae) for controlling sugarcane moth borers in Thailand. Sugar Tech 19, 616-622. doi: 10.1007/s12355-017-0530-x

Matteson, P. C. (2000). Insect pest management in tropical Asian irrigated rice. Annu. Rev. Entomol. 45, 549-574. doi: 10.1146/annurev.ento.45.1.549

Maxwell, S. L., Fuller, R. A., Brooks, T., and Watson, J. (2016). The ravages of guns, nets and bulldozers. Nature 536, 144-146. doi: 10.1038/536143a

Mills, J., Gaskell, P., Ingram, J., Dwyer, J., Reed, M., and Short, C. (2017). Engaging farmers in environmental management through a better understanding of behaviour. Agric. Hum. Values 34, 283-299. doi: 10.1007/s10460-016-9705-4

Morallo-Rejesus, B., Inocencio, E. L., Malabanan-Manipol, J., Eusebio, J. E., and Barroga, S. F. (2000). Technology transfer of Cotesia-based IPM for diamondback moth on lower elevation crucifers in Luzon. Philipp. Entomol. $14,73-87$.

Naranjo, S. E., Ellsworth, P. C., and Frisvold, G. B. (2015). Economic value of biological control in integrated pest management of managed plant systems. Annu. Rev. Entomol. 60, 621-645. doi: 10.1146/annurev-ento-010814-0 21005

Nga, L. T., and Kumar, P. (2008). Contributions of parasitoids and Bacillus thuringiensis to the management of diamondback moth in highland crucifer production in Da Lat, Vietnam. J. Asia Pac. Entomol. 11, 59-64. doi: 10.1016/j.aspen.2008.05.002

Nghiem, L. T., Soliman, T., Yeo, D. C., Tan, H. T., Evans, T. A., Mumford, J. D., et al. (2013). Economic and environmental impacts of harmful non-indigenous species in Southeast Asia. PLoS ONE 8:e71255. doi: 10.1371/journal.pone.0071255

Offenberg, J. (2014). The use of artificial nests by weaver ants: a preliminary field observation. Asian Myrmecol. 6, 119-128. doi: 10.20362/am.006011

Onstad, D. W., and Knolhoff, L. M. (2009). Finding the economics in economic entomology. J. Econ. Entomol. 102, 1-7. doi: 10.1603/029.102.0101

Phillips, B. W., and Gardiner, M. M. (2015). Use of video surveillance to measure the influences of habitat management and landscape composition on pollinator visitation and pollen deposition in pumpkin (Cucurbita pepo) agroecosystems. PeerJ. 3:e1342. doi: 10.7717/peerj.1342

Pimentel, D., Wilson, C., McCullum, C., Huang, R., Dwen, P., Flack, J., et al. (1997). Economic and environmental benefits of biodiversity. Bioscience 47, 747-757. doi: $10.2307 / 1313097$

Pingali, P. L. (2012). Green revolution: impacts, limits, and the path ahead. Proc. Natl. Acad. Sci. U.S.A. 109, 12302-12308. doi: 10.1073/pnas.0912953109
Pontius, J. (2002). From Farmer Field School to Community IPM: Ten Years of IPM Training in Asia. Bangkok: FAO Community IPM Programme, Food and Agriculture Organization of the United Nations, Regional Office for Asia and the Pacific.

Poore, J., and Nemecek, T. (2018). Reducing food's environmental impacts through producers and consumers. Science 360, 987-992. doi: 10.1126/science.aaq0216

Praneetvatakul, S., Schreinemachers, P., Pananurak, P., and Tipraqsa, P. (2013). Pesticides, external costs and policy options for Thai agriculture. Environ. Sci. Policy 27, 103-113. doi: 10.1016/j.envsci.2012.10.019

Pretty, J., Benton, T. G., Bharucha, Z. P., Dicks, L. V., Flora, C. V., Godfray, H. C. J., et al. (2018). Global assessment of agricultural system redesign for sustainable intensification. Nat. Sustain. 1, 441-446. doi: 10.1038/s41893-018-0114-0

Pretty, J., and Bharucha, Z. P. (2015). Integrated pest management for sustainable intensification of agriculture in Asia and Africa. Insects 6, 152-182. doi: 10.3390/insects6010152

Röling, N., and Van De Fliert, E. (1994). Transforming extension for sustainable agriculture: the case of integrated pest management in rice in Indonesia. Agric. Hum. Values 11, 96-108. doi: 10.1007/BF01530451

Ruesink, W. G. (1976). Status of the systems approach to pest management. Annu. Rev. Entomol. 21, 27-44. doi: 10.1146/annurev.en.21.010176.000331

Sartas, M., Schut, M., van Schagen, B., Velasco, C., Thiele, G., Proietti, C., and Leeuwis, C. (2020). Scaling Readiness: Concepts, Practices, and Implementation. Lima: CGIAR Research Program on Roots, Tubers and Bananas (RTB).

Schoenly, K. G., Justo, H. D. Jr., Barrion, A. T., Harris, M. K., and Bottrell, D. G. (1998). Analysis of invertebrate biodiversity in a Philippine farmer's irrigated rice field. Environ. Entomol. 27, 1125-1136. doi: 10.1093/ee/27.5.1125

Schreinemachers, P., Grovermann, C., Praneetvatakul, S., Heng, P., Nguyen, T. T. L., Buntong, B., et al. (2020). How much is too much? Quantifying pesticide overuse in vegetable production in Southeast Asia. J. Cleaner Prod. 244:118738. doi: 10.1016/j.jclepro.2019.118738

Settle, W. H., Ariawan, H., Astuti, E. T., Cahyana, W., Hakim, A. L., Hindayana, D., et al. (1996). Managing tropical rice pests through conservation of generalist natural enemies and alternative prey. Ecology 77, 1975-1988. doi: $10.2307 / 2265694$

Shea, K., Possingham, H. P., Murdoch, W. W., and Roush, R. (2002). Active adaptive management in insect pest and weed control: intervention with a plan for learning. Ecol. Appl. 12, 927-936. doi: 10.1890/1051-0761(2002)0120927:AAMIIP2.0.CO;2

Shields, M. W., Johnson, A. C., Pandey, S., Cullen, R., González-Chang, M., Wratten, S. D., et al. (2019). History, current situation and challenges for conservation biological control. Biol. Control 131, 25-35. doi: 10.1016/j.biocontrol.2018.12.010

Snapp, S. S., Blackie, M. J., Gilbert, R. A., Bezner-Kerr, R., and Kanyama-Phiri, G. Y. (2010). Biodiversity can support a greener revolution in Africa. Proc. Natl. Acad. Sci. U.S.A. 107, 20840-20845. doi: 10.1073/pnas.1007199107

Springmann, M., Clark, M., Mason-D'Croz, D., Wiebe, K., Bodirsky, B. L., Lassaletta, L., et al. (2018). Options for keeping the food system within environmental limits. Nature 562, 519-525. doi: 10.1038/s41586-018-0594-0

Steffen, W., Richardson, K., Rockström, J., Cornell, S. E., Fetzer, I., Bennett, E. M., et al. (2015). Planetary boundaries: guiding human development on a changing planet. Science 347:1259855. doi: 10.1126/science.1259855

Teng, P. S., and Savary, S. (1992). Implementing the systems approach in pest management. Agric. Syst. 40, 237-264. doi: 10.1016/0308-521X(92)9 0023-H

Thelwall, M. (2018). Dimensions: a competitor to scopus and the web of science? J. Inf. 12, 430-435. doi: 10.1016/j.joi.2018.03.006

Thorburn, C. (2015). The rise and demise of integrated pest management in rice in Indonesia. Insects 6, 381-408. doi: 10.3390/insects6020381

Tilman, D. (1998). The greening of the green revolution. Nature 396, 211-212. doi: $10.1038 / 24254$

Upadhyay, B., Burra, D. D., Nguyen, T. T., and Wyckhuys, K. A. (2020). Caught off guard: folk knowledge proves deficient when addressing invasive pests in Asian cassava systems. Environ. Dev. Sustain. 22, 425-445. doi: 10.1007/s10668-018-0208-x

van de Fliert, E., Dung, N. T., Henriksen, O., and Dalsgaard, J. P. T. (2007) From collectives to collective decision-making and action: farmer field schools in Vietnam. J. Agric. Educ. Ext. 13, 245-256. doi: 10.1080/138922407014 27706 
Van Mele, P., and Cuc, N. T. T. (2000). Evolution and status of Oecophylla smaragdina (fabricius) as a pest control agent in citrus in the mekong delta, Vietnam. Int. J. Pest Manag. 46, 295-301. doi: 10.1080/09670870050206073

Vandermeer, J., Aga, A., Allgeier, J., Badgley, C., Baucom, R., Blesh, J., et al. (2018). Feeding prometheus: an interdisciplinary approach for solving the global food crisis. Front. Sustain. Food Syst. 2:39. doi: 10.3389/fsufs.2018.00039

Veen, C., Wubs, J., Bardgett, R., Barrios, E., Bradford, M., Carvalho, S., et al. (2019). Applying the aboveground-belowground interaction concept in agriculture: spatio-temporal scales matter. Front. Ecol. Evol. 7:300. doi: 10.3389/fevo.2019.00300

Wanger, T. C., Darras, K., Bumrungsri, S., Tscharntke, T., and Klein, A. M. (2014). Bat pest control contributes to food security in Thailand. Biol. Conserv. 171, 220-223. doi: 10.1016/j.biocon.2014.01.030

Waterhouse, D. F. (1998). Biological Control of Insect Pests: Southeast Asian Prospects. Canberra, ACT: ACIAR.

Westphal, C., Vidal, S., Horgan, F. G., Gurr, G. M., Escalada, M., Van Chien, H., et al. (2015). Promoting multiple ecosystem services with flower strips and participatory approaches in rice production landscapes. Basic Appl. Ecol. 16, 681-689. doi: 10.1016/j.baae.2015.10.004

Wigboldus, S., Klerkx, L., Leeuwis, C., Schut, M., Muilerman, S., and Jochemsen, H. (2016). Systemic perspectives on scaling agricultural innovations. A review. Agron. Sustain. Dev. 36:46. doi: 10.1007/s13593-016-0 $380-\mathrm{z}$

Willett, W., Rockström, J., Loken, B., Springmann, M., Lang, T., Vermeulen, S., et al. (2019). Food in the anthropocene: the EAT-lancet commission on healthy diets from sustainable food systems. Lancet 393, 447-492. doi: 10.1016/S0140-6736(18)31788-4

Wilson, E. O. (2017). Biodiversity research requires more boots on the ground. Nat. Ecol. Evol. 1, 1590-1591. doi: 10.1038/s41559-017-0 $360-y$

Wulf, A. (2015). The Invention of Nature: The Adventures of Alexander von Humboldt, the Lost Hero of Science. London: John Murray Publishers.

Wyckhuys, K., Burra, D., Tran, D., Graziosi, I., Walter, A., Nguyen, T., et al. (2017). Soil fertility regulates invasive herbivore performance and top-down control in tropical agroecosystems of Southeast Asia. Agric. Ecosyst. Environ. 249, 38-49. doi: 10.1016/j.agee.2017.08.006
Wyckhuys, K. A. G., Heong, K. L., Sánchez-Bayo, F., Bianchi, F. J. J. A., Lundgren, J. G., and Bentley, J. W. (2019). Ecological illiteracy can deepen farmers' pesticide dependency. Environ. Res. Lett. 14:093004. doi: 10.1088/1748-9326/ab34c9

Yanuwiadi, B. (2017). "Farmers' perception of the role of some wild plants for the predatory coccinellidae (Adalia bipunctata $\mathrm{L}$ and Coccinella septempunctata $\mathrm{L}$ ) in developing refugia in the agricultural field," in AIP Conference Proceedings 1908 (Malang). doi: 10.1063/1.5012702

Yletyinen, J., Brown, P., Pech, R., Hodges, D., Hulme, P. E., Malcolm, T. F., et al. (2019). Understanding and managing social-ecological tipping points in primary industries. BioScience 69, 335-347. doi: 10.1093/biosci/biz031

Zhang, W., Cao, G., Li, X., Zhang, H., Wang, C., Liu, Q., et al. (2016). Closing yield gaps in China by empowering smallholder farmers. Nature 537, 671-674. doi: 10.1038/nature19368

Zhu, P., Lu, Z., Heong, K., Chen, G., Zheng, X., Xu, H., et al. (2014). Selection of nectar plants for use in ecological engineering to promote biological control of rice pests by the predatory bug, Cyrtorhinus lividipennis (Heteroptera: Miridae). PLoS ONE 9:e108669. doi: 10.1371/journal.pone.0108669

Zimmerer, K. S. (2006). Humboldt's nodes and modes of interdisciplinary environmental science in the andean world. Geogr. Rev. 96, 335-360. doi: 10.1111/j.1931-0846.2006.tb00255.x

Conflict of Interest: GA was employed by "The New Zealand Institute for Plant and Food Research Limited" company.

The remaining authors declare that the research was conducted in the absence of any commercial or financial relationships that could be construed as a potential conflict of interest.

Copyright (c) 2020 Wyckhuys, González-Chang, Adriani, Albaytar, Albertini, Avila, Beltran, Boreros, Fanani, Nguyen, Nguyen, Nurkomar and Tiwari. This is an open access article distributed under the terms of the Creative Commons Attribution License (CC BY). The use, distribution or reproduction in other forums is permitted provided the original author(s) and the copyright owner(s) are credited and that the original publication in this journal is cited, in accordance with accepted academic practice. No use, distribution or reproduction is permitted which does not comply with these terms. 